\title{
Solusi Numerik Model Gerak Osilasi Vertikal dan Torsional Pada Jembatan Gantung
}

\author{
Hendrik Widya Permata1 ${ }^{1}$ Ari Kusumastuti², Juhari ${ }^{3}$ \\ 1Mahasiswa Jurusan Matematika Universitas Islam Negeri Maulana Malik Ibrahim Malang \\ 2,3Dosen Jurusan Matematika Universitas Islam Negeri Maulana Malik Ibrahim Malang
}

Email: hendrikpermata42@gmail.com, arikusumastuti@gmail.com, juhari@uin-malang.ac.id

\begin{abstract}
ABSTRAK
Model gerak osilasi vertikal dan torsional merupakan model yang menggambarkan gerak osilasi vertikal dan gerak torsional pada batang yang digantung. Gerak osilasi vertikal merupakan gerak naik turun suatu benda yang terjadi terus berulang, dan kemudian pada waktu tertentu akan berhenti atau mengalami redaman. Gerak torsional merupakan getaran sudut dari suatu objek yang mengalami rotasi. Model gerak osilasi dan torsional pada dasarnya merupakan sistem persamaan diferensial orde dua. Tujuan dari penelitian ini adalah untuk mengetahui solusi numerik model gerak osilasi vertikal dan torsional menggunakan metode Adams-BashforthMoulton orde empat, lima, dan enam. Model gerak osilasi vertikal dan torsional terlebih dahulu diselesaikan menggunakaan metode Runge-Kutta-Fehlberg orde lima untuk mendapatkan solusi awal kemudian model tersebut diselesaikan menggunakan metode Adams-Bashforth-Moulton orde empat, lima dan enam. Hasil solusi numerik setiap metode Adam-Bashforth-Moulton selanjutnya diuji dengan galat relatif. Hasil simulasi numerik model gerak osilasi vertikal dan torsi diperoleh bahwa gerak osilasi vertikal dan gerak torsional merupakan gerak harmonik teredam dan semakin tinggi orde pada metode Adams-Bashforth-Moulton maka akan lebih cepat galat relatif menuju nilai nol dan sebaliknya.
\end{abstract}

Kata kunci: gerak osilasi, gerak torsional, metode Adams-Bashforth-Moulton

\begin{abstract}
Vertical and torsional oscillatory motion models are models that describe the vertical oscillatory motion and torsional motion of a hanging rod. Vertical oscillatory motion is an up and down motion of an object that occurs repeatedly, and then at a certain time will stop or experience attenuation. Torsional motion is the angular vibration of an object undergoing rotation. The oscillatory and torsional motion models are basically a system of second-order differential equations. The purpose of this study was to determine the numerical solution of the vertical and torsional oscillatory motion models using the Adams-Bashforth-Moulton method of order four, five, and six. The vertical and torsional oscillatory motion models were first solved using the fifthorder Runge-Kutta-Fehlberg method to get an initial solution, then the model was solved using the fourth, fifth and sixth-order Adams-Bashforth-Moulton methods. The results of the numerical solution of each Adam-Bashforth-Moulton method were then tested with relative errors. The numerical simulation results of the vertical and torsional oscillation models show that the vertical oscillating motion and torsional motion are damped harmonic motions and the higher the order in the Adams-Bashforth-Moulton method, the faster the relative error will go to zero and vice versa.
\end{abstract}

Keywords: oscillatory motion, torsional motion, Adams-Bashforth-Moulton method 


\section{PENDAHULUAN}

Matematika memberikan peran penting terhadap kemajuan ilmu pengetahuan dan teknologi dari tahun ke tahun. Salah satunya pada pemodelan matematika, karena hampir semua kejadian-kejadian dan fenomena di muka bumi ini dapat diformulasikan ke dalam matematika. Salah satu fenomena yang dikaji adalah masalah getaran pada objek benda-benda yang bergetar, salah satu contohnya adalah getaran pada jembatan gantung.

Permasalahan getaran jembatan gantung yang banyak diperbincangkan peneliti dimulai ketika runtuhnya jembatan Tacoma Narrow. Salah satu peneliti yakni McKenna mengungkapkan bahwa penyebab runtuhnya jembatan Tacoma Narrow karena adanya keberadaan kabel vertikal yang menahan pergerakan rentang tengah jembatan ke bawah karena terhuyung. Sehingga pada tahun 1999, McKenna mengkontruksi sebuah model matematika terhadap jembatan gantung Tacoma Narrow. Kemudian pada tahun 2012, Kwofie menggunakan model McKenna (1999) yang diterapkan pada jembatan Adomi. Model tersebut menceritakan masalah getaran yang terjadi pada penampang jembatan yang berupa gerak osilasi vertikal dan torsional [1].

Gerak osilasi merupakan suatu getaran yang terjadi secara berulang dalam selang waktu dan pada lintasan yang sama. Dimana suatu getaran yang mengalami gerak osilasi lama-kelamaan akan menuju pada titik kesetimbanganya. Sedangkan suatu gerak yang mengakibatkan suatu objek berputar pada sumbu poros disebut dengan gerak rotasi, dengan besaran yang bekerja pada suatu benda yang mengalami rotasi disebut dengan gerak torsional. Persamaan gerak osilasi dan torsional dinyatakan sebagai persamaan diferensial biasa yang bergantung pada waktu $t$ [2].

Penyelesaian numerik persamaan diferensial biasa terdiri dari dua metode yaitu metode satu langkah dan metode multi-langkah. Pada metode satu langkah, untuk mendapatkan taksiran nilai $y\left(t_{n+1}\right)$ membutuhkan satu nilai taksiran sebelumnya yaitu $y\left(t_{n}\right)$ dalam proses perhitungannya. Dalam metode satu-langkah terdiri dari berbagai macam metode yaitu metode Euler, metode Heun, dan metode Runge-Kutta. Sedangan pada metode multi-langkah, untuk mendapatkan nilai taksiran $y\left(t_{n+1}\right)$ membutuhkan beberapa nilai taksiran sebelumnya yaitu $y\left(t_{n}\right), y\left(t_{n-1}\right), y\left(t_{n-2}\right), \ldots$ dalam proses perhitungannya. Yang termasuk dalam metode multi-langkah adalah metode prediktorkorektor [3]. Metode prediktor-korektor merupakan metode yang menaksir nilai $y\left(t_{n+1}\right)$ dari $y\left(t_{n}\right), y\left(t_{n-1}\right), y\left(t_{n-2}\right), \ldots$ dalam persamaan prediktor dan kemudian menggunakan persamaan korektor untuk memperbaiki nilai $y_{n+1}$ dari prediktor. Metode prediktorkorektor pada dasarnya terdiri dari metode Adams-Bashforth-Moulton, metode MilneSimpson, dan metode Hamming [4]-[5]. Penelitian sebelumnya dilakukan [6] dalam bentuk persamaan diferensial parsial untuk model gerak osilasi vertikal dan torsional dawai.

Berdasarkan beberapa penelitian tersebut, maka penelitian ini akan mengkaji model yang menggambarkan gerak osilasi vertikal dan gerak torsional pada batang yang digantung menggunakan metode Adams-Bashforth-Moulton orde empat, lima dan enam.

\section{METODE}

Berdasarkan uraian di atas, maka metode yang penulis gunakan dalam penelitian ini adalah studi literatur. Adapun langkah-langkah dalam penelitian ini sebagai berikut:

1. Penyelesaian numerik dengan langkah-langkah sebagai berikut:

a. Mereduksi sistem persamaan diferensial orde dua menjadi sistem persamaan diferensial orde satu. 
b. Menentukkan solusi awal menggunakan metode Runge-Kutta- Fehlberg orde lima.

c. Menentukkan solusi numerik menggunakan metode Adams-Bashforth-Moulton orde empat, metode Adams-Bashforth-Moulton orde lima, dan metode AdamsBashforth-Moulton orde enam.

d. Menentukkan galat relatif dari solusi numerik metode Adams-Bashforth-Moulton orde empat, metode Adams-Bashforth-Moulton orde lima, dan metode AdamsBashforth-Moulton orde enam.

2. Simulasi numerik dengan langkah-langkah sebagai berikut:

a. Memasukan nilai parameter-parameter pada model gerak osilasi vertikal dan torsional.

b. Memisalkan nilai awal pada model gerak osilasi vertikal dan torsional.

c. Perbandingan simulasi numerik dengan langkah-langkah sebagai berikut:

d. Membandingkan solusi numerik dan galat relatif metode Adams-BashforthMoulton orde empat, metode Adams-Bashforth-Moulton orde lima, dan metode Adams-Bashforth-Moulton orde enam pada model gerak osilasi vertikal dan torsioanal.

e. Interpretasi grafik solusi numerik dan grafik galat relatif pada model gerak osilasi vertikal dan torsional.

\section{HASIL DAN PEMBAHASAN}

\section{Analisis Model Gerak Osilasi Vertikal dan Torsional}

Penelitian ini merujuk pada jurnal Kwofie (2012) yang mengemukakan bahwa model gerak osilasi vertikal dan torsional adalah:

$$
\left\{\begin{array}{l}
\ddot{y}(t)=-\frac{K}{m}\left[(y(t)-l \sin (\theta(t)))^{+}+(y(t)+l \sin (\theta(t)))^{+}\right]-\delta_{2} \dot{y}(t)+g \\
\ddot{\theta}(t)=\frac{3 K}{m l} \cos (\theta(t))\left[(y(t)-l \sin (\theta(t)))^{+}-(y(t)+l \sin (\theta(t)))^{+}\right]-\delta_{1} \dot{\theta}(t)+f(t)
\end{array}\right.
$$

dimana $f(t)=\alpha \sin (\mu t)$. Persamaan (1) merupakan sistem persamaan diferensial biasa orde dua. Pada dasarnya sistem persamaan diferensial biasa orde dua dapat direduksi menjadi sistem persamaaan diferensil biasa orde satu. Karena penyelesain metode Adams-Bashforth-Moulton sebagai prediktor-korektor harus berupa sistem persamaan diferensial biasa orde satu.

Sehingga dengan memisalkan

dan turunan (2) terhadap $t$ yaitu

$$
y_{1}(t)=y(t), y_{2}(t)=\dot{y}(t), \theta_{1}(t)=\theta(t), \quad \text { dan } \quad \theta_{2}(t)=\dot{\theta}(t)
$$

$$
\dot{y}_{1}(t)=\dot{y}(t), \dot{y}_{2}(t)=\ddot{y}(t), \dot{\theta}_{1}(t)=\dot{\theta}(t), \quad \text { dan } \quad \dot{\theta}_{2}(t)=\ddot{\theta}(t) .
$$

Maka model gerak osilasi vertikal dan torsional dapat ditulis menjadi 


$$
\left\{\begin{aligned}
\dot{y}_{1}(t)=p\left(t, y_{1}, y_{2}, \theta_{1}, \theta_{2}\right)= & y_{2}(t) \\
\dot{y}_{2}(t)=q\left(t, y_{1}, y_{2}, \theta_{1}, \theta_{2}\right)= & -\frac{K}{m}\left[\left(y_{1}(t)-l \sin \left(\theta_{1}(t)\right)\right)^{+}+\left(y_{1}(t)+l \sin \left(\theta_{1}(t)\right)\right)^{+}\right] \\
& -\delta_{2} y_{2}(t)+g \\
\dot{\theta}_{1}(t)=r\left(t, y_{1}, y_{2}, \theta_{1}, \theta_{2}\right)= & \theta_{2}(t) \\
\dot{\theta}_{2}(t)=s\left(t, y_{1}, y_{2}, \theta_{1}, \theta_{2}\right)= & \frac{3 K}{m l} \cos \left(\theta_{1}(t)\right)\left[\left(y_{1}(t)-l \sin \left(\theta_{1}(t)\right)\right)^{+}-\left(y_{1}(t)+l \sin \left(\theta_{1}(t)\right)\right)^{+}\right] \\
& -\delta_{1} \theta_{2}(t)+f(t)
\end{aligned}\right.
$$

dengan $y_{1}$ merupakan jarak batang jembatan gantung, $y_{2}$ merupakan kecepatan perubahan jarak batang, $\theta_{1}$ merupakan besarnya sudut batang, dan $\theta_{2}$ merupakan kecepatan perubahan sudut batang.

\section{Pengembangan Metode Adams-Bashforth-Moulton}

Pengembangan metode Adams-Bashforth-Moulton terdiri dari

1. Rumus metode Adams-Bashforth-Moulton orde empat

Rumus prediktor metode Adams-Bashforth-Moulton orde empat adalah

$$
y_{n+1}^{(i)}=y_{n}+\frac{h}{24}\left(55 f_{n}-59 f_{n-1}+37 f_{n-2}-9 f_{n-3}\right)
$$

Rumus korektor metode Adams-Bashforth-Moulton orde empat adalah

$$
y_{n+1}^{(i+1)}=y_{n}+\frac{h}{24}\left[f_{n-2}-5 f_{n-1}+19 f_{n}+9 f\left(x_{n+1}, y_{n+1}^{(i)}\right)\right]
$$

2. Rumus metode Adams-Bashforth-Moulton orde lima

Rumus prediktor metode Adams-Bashforth-Moulton orde lima adalah

$$
y_{n+1}=y_{n}+\frac{h}{720}\left[1901 f_{n}-2774 f_{n-1}+2616 f_{n-2}-1274 f_{n-3}+251 f_{n-4}\right] .
$$

Rumus korektor metode Adams-Bashforth-Moulton orde lima adalah

$$
y_{n+1}^{(i+1)}=y_{n}+\frac{h}{720}\left(-19 f_{n-3}+106 f_{n-2}-264 f_{n-1}+646 f_{n}+251 f_{n+1}\left(y_{n+1}^{(i)}\right)\right)
$$

3. Rumus metode Adams-Bashforth-Moulton orde enam

Rumus prediktor metode Adams-Bashforth-Moulton orde enam adalah

$$
y_{n+1}=y_{n}+\frac{h}{1440}\left[4274 f_{n}-7908 f_{n-1}+9952 f_{n-2}-7268 f_{n-3}+2862 f_{n-4}-472 f_{n-5}\right] \text {. }
$$

Rumus korektor metode Adams-Bashforth-Moulton orde enam adalah

$$
y_{n+1}^{(i+1)}=y_{n}+\frac{h}{1440}\left[27 f_{n-4}-173 f_{n-3}+482 f_{n-2}-798 f_{n-1}+1427 f_{n}+475 f\left(x_{n+1}, y_{n+1}^{(i)}\right)\right]
$$

\section{Penyelesaian Numerik Model Gerak Osilasi Vertikal dan Torsional}

Penyelesain model gerak osilasi vertikal dan torsional dengan metode AdamsBashforth-Moulton adalah sebagai berikut:

1. Diberikan nilai awal model gerak osilasi vertikal dan torsional (1) yaitu 


$$
\begin{aligned}
& y_{1}(0)=y_{1(0)} \\
& y_{2}(0)=y_{2(0)} \\
& \theta_{1}(0)=\theta_{1(0)} \\
& \theta_{2}(0)=\theta_{2(0)}
\end{aligned}
$$

dengan ukuran langkah $h$ tetap dan $t_{n+1}=t_{n}+h$.

2. Hitung solusi awal dari $y_{1(j)}, y_{2(j)}, \theta_{1(j)}$, dan $\theta_{2(j)}$ menggunakan metode Runge-KuttaFehlberg orde lima dimana $j=0,1,2,3$ untuk metode Adams-Bashforth-Moulton orde empat; $j=0,1,2,3,4$ untuk metode Adams-Bashforth-Moulton orde lima; dan $j=0,1,2,3,4,5$ untuk metode Adams-Bashforth-Moulton orde enam.

3. Menentukkan nilai-nilai dari $p_{n-j}, q_{n-j}, r_{n-j}$, dan $s_{n-j}$ dimana $j=0,1,2,3$ dan $n=3,4,5, \ldots$ untuk metode Adams-Bashforth-Moulton orde empat; $j=0,1,2,3,4$ dan $n=4,5,6, \ldots$ untuk metode Adams-Bashforth-Moulton orde lima; dan $j=0,1,2,3,4,5$ dan $n=5,6,7, \ldots$ untuk metode Adams-Bashforth-Moulton orde enam.

4. Hitung solusi numerik menggunakan metode Adams-Bashforth sebagai berikut:

$$
\begin{aligned}
y_{1(n+1)}^{(i)} & =y_{1(n)}+\frac{h}{24}\left(55 p_{n}-59 p_{n-1}+37 p_{n-2}-9 p_{n-3}\right) \\
y_{2(n+1)}^{(i)} & =y_{2(n)}+\frac{h}{24}\left(55 q_{n}-59 q_{n-1}+37 q_{n-2}-9 q_{n-3}\right) \\
\theta_{1(n+1)}^{(i)} & =\theta_{1(n)}+\frac{h}{24}\left(55 r_{n}-59 r_{n-1}+37 r_{n-2}-9 r_{n-3}\right) \\
\theta_{2(n+1)}^{(i)} & =\theta_{2(n)}+\frac{h}{24}\left(55 s_{n}-59 s_{n-1}+37 s_{n-2}-9 s_{n-3}\right)
\end{aligned}
$$

untuk proses perhitungan metode Adams-Bashforth-Moulton orde empat,

$$
\begin{aligned}
& y_{1(n+1)}^{(i)}=y_{1(n+1)}+\frac{h}{720}\left(1901 p_{n}-2774 p_{n-1}+2616 p_{n-2}-1274 p_{n-3}+251 p_{n-4}\right) \\
& y_{2(n+1)}^{(i)}=y_{2(n+1)}+\frac{h}{720}\left(1901 q_{n}-2774 q_{n-1}+2616 q_{n-2}-1274 q_{n-3}+251 q_{n-4}\right) \\
& \theta_{1(n+1)}^{(i)}=\theta_{1(n+1)}+\frac{h}{720}\left(1901 r_{n}-2774 r_{n-1}+2616 r_{n-2}-1274 r_{n-3}+251 r_{n-4}\right) \\
& \theta_{2(n+1)}^{(i)}=\theta_{2(n+1)}+\frac{h}{720}\left(1901 s_{n}-2774 s_{n-1}+2616 s_{n-2}-1274 s_{n-3}+251 s_{n-4}\right)
\end{aligned}
$$

untuk proses perhitungan metode Adams-Bashforth-Moulton orde lima, dan

$$
\begin{aligned}
& y_{1(n+1)}^{(i)}=y_{1(n)}+\frac{h}{1440}\left(4274 p_{n}-7908 p_{n-1}+9952 p_{n-2}-7268 p_{n-3}+2862 p_{n-4}-472 p_{n-5}\right) \\
& y_{2(n+1)}^{(i)}=y_{2(n)}+\frac{h}{1440}\left(4274 q_{n}-7908 q_{n-1}+9952 q_{n-2}-7268 q_{n-3}+2862 q_{n-4}-472 q_{n-5}\right) \\
& \theta_{1(n+1)}^{(i)}=\theta_{1(n)}+\frac{h}{1440}\left(4274 r_{n}-7908 r_{n-1}+9952 r_{n-2}-7268 r_{n-3}+2862 r_{n-4}-472 r_{n-5}\right) \\
& \theta_{2(n+1)}^{(i)}=\theta_{2(n)}+\frac{h}{1440}\left(4274 s_{n}-7908 s_{n-1}+9952 s_{n-2}-7268 s_{n-3}+2862 s_{n-4}-472 s_{n-5}\right)
\end{aligned}
$$

untuk proses perhitungan metode Adams-Bashforth-Moulton orde enam.

5. Hitung solusi numerik menggunakan metode Adams-Moulton sebagai berikut: 


$$
\begin{aligned}
& y_{1(n+1)}^{(i+1)}=y_{1(n)}+\frac{h}{24}\left(p_{n-2}-5 p_{n-1}+19 p_{n}+9 p\left(t_{(n+1)}, y_{1(n+1)}^{(i)}, y_{2(n+1)}^{(i)}, \theta_{1(n+1)}^{(i)}, \theta_{2(n+1)}^{(i)}\right)\right) \\
& y_{2(n+1)}^{(i+1)}=y_{2(n)}+\frac{h}{24}\left(q_{n-2}-5 q_{n-1}+19 q_{n}+9 q\left(t_{(n+1)}, y_{1(n+1)}^{(i)}, y_{2(n+1)}^{(i)}, \theta_{1(n+1)}^{(i)}, \theta_{2(n+1)}^{(i)}\right)\right) \\
& \theta_{1(n+1)}^{(i+1)}=\theta_{1(n)}+\frac{h}{24}\left(r_{n-2}-5 r_{n-1}+19 r_{n}+9 r\left(t_{(n+1)}, y_{1(n+1)}^{(i)}, y_{2(n+1)}^{(i)}, \theta_{1(n+1)}^{(i)}, \theta_{2(n+1)}^{(i)}\right)\right) \\
& \theta_{2(n+1)}^{(i+1)}=\theta_{2(n)}+\frac{h}{24}\left(s_{n-2}-5 s_{n-1}+19 s_{n}+9 s\left(t_{(n+1)}, y_{1(n+1)}^{(i)}, y_{2(n+1)}^{(i)}, \theta_{1(n+1)}^{(i)}, \theta_{2(n+1)}^{(i)}\right)\right)
\end{aligned}
$$

untuk proses perhitungan metode Adams-Bashforth-Moulton orde empat,

$$
\begin{aligned}
& y_{1(n+1)}^{(i+1)}=y_{1(n)}+\frac{h}{720}\left(-19 p_{n-3}+106 p_{n-2}-264 p_{n-1}+646 p_{n}+251 p\left(t_{n+1}, y_{1(n+1)}^{(i)}, y_{2(n+1)}^{(i)}, \theta_{1(n+1)}^{(i)}, \theta_{2(n+1)}^{(i)}\right)\right) \\
& y_{2(n+1)}^{(i+1)}=y_{2(n)}+\frac{h}{720}\left(-19 q_{n-3}+106 q_{n-2}-264 q_{n-1}+646 q_{n}+251 q\left(t_{n+1}, y_{1(n+1)}^{(i)}, y_{2(n+1)}^{(i)}, \theta_{1(n+1)}^{(i)}, \theta_{2(n+1)}^{(i)}\right)\right) \\
& \theta_{1(n+1)}^{(i+1)}=\theta_{1(n)}+\frac{h}{720}\left(-19 r_{n-3}+106 r_{n-2}-264 r_{n-1}+646 r_{n}+251 r\left(t_{n+1}, y_{1(n+1)}^{(i)}, y_{2(n+1)}^{(i)}, \theta_{1(n+1)}^{(i)}, \theta_{2(n+1)}^{(i)}\right)\right) \\
& \theta_{2(n+1)}^{(i+1)}=\theta_{2(n)}+\frac{h}{720}\left(-19 s_{n-3}+106 s_{n-2}-264 s_{n-1}+646 s_{n}+251 s\left(t_{n+1}, y_{1(n+1)}^{(i)}, y_{2(n+1)}^{(i)}, \theta_{1(n+1)}^{(i)}, \theta_{2(n+1)}^{(i)}\right)\right)
\end{aligned}
$$

untuk proses perhitungan metode Adams-Bashforth-Moulton orde lima, dan

$$
\begin{aligned}
& y_{1(n+1)}^{(i+1)}=y_{1(n)}+\frac{h}{1440}\left(27 p_{n-4}-173 p_{n-3}+482 p_{n-2}-798 p_{n-1}+1427 p_{n}+475 p\left(t_{n+1}, y_{1(n+1)}^{(i)}, y_{2(n+1)}^{(i)}, \theta_{1(n+1)}^{(i)}, \theta_{2(n+1)}^{(i)}\right)\right) \\
& y_{2(n+1)}^{(i+1)}=y_{2(n)}+\frac{h}{1440}\left(27 q_{n-4}-173 q_{n-3}+482 q_{n-2}-798 q_{n-1}+1427 q_{n}+475 q\left(t_{n+1}, y_{1(n+1)}^{(i)}, y_{2(n+1)}^{(i)}, \theta_{1(n+1)}^{(i)}, \theta_{2(n+1)}^{(i)}\right)\right) \\
& \theta_{1(n+1)}^{(i+1)}=\theta_{1(n)}+\frac{h}{1440}\left(27 r_{n-4}-173 r_{n-3}+482 r_{n-2}-798 r_{n-1}+1427 r_{n}+475 r\left(t_{n+1}, y_{1(n+1)}^{(i)}, y_{2(n+1)}^{(i)}, \theta_{1(n+1)}^{(i)}, \theta_{2(n+1)}^{(i)}\right)\right) \\
& \theta_{2(n+1)}^{(i+1)}=\theta_{2(n)}+\frac{h}{1440}\left(27 r_{n-4}-173 r_{n-3}+482 r_{n-2}-798 r_{n-1}+1427 r_{n}+475 r\left(t_{(n+1)}, y_{1(n+1)}^{(i)}, y_{2(n+1)}^{(i)}, \theta_{1(n+1)}^{(i)}, \theta_{2(n+1)}^{(i)}\right)\right)
\end{aligned}
$$

untuk proses perhitungan metode Adams-Bashforth-Moulton orde enam.

6. Hitung galat relatif,

$$
\begin{gathered}
\frac{\left|y_{1(n+1)}^{(i+1)}-y_{1(n+1)}^{(i)}\right|}{\left|y_{1(n+1)}^{(i+1)}\right|} \leq \varepsilon, \\
\frac{\left|y_{2(n+1)}^{(i+1)}-y_{2(n+1)}^{(i)}\right|}{\left|y_{2(n+1)}^{(i+1)}\right|} \leq \varepsilon, \\
\frac{\left|\theta_{1(n+1)}^{(i+1)}-\theta_{1(n+1)}^{(i)}\right|}{\left|\theta_{1(n+1)}^{(i+1)}\right|} \leq \varepsilon,
\end{gathered}
$$

dan

$$
\frac{\left|\theta_{2(n+1)}^{(i+1)}-\theta_{2(n+1)}^{(i)}\right|}{\left|\theta_{2(n+1)}^{(i+1)}\right|} \leq \varepsilon
$$

dimana $i=0,1,2,3,4, \ldots$ dan $\varepsilon$ merupakan kriteria pemberhentian. Jika kondisi (4) tidak terpenuhi maka nilai $y_{1(n+1)}^{(i+1)}, y_{2(n+1)}^{(i+1)}, \theta_{1(n+1)}^{(i+1)}$, dan $\theta_{2(n+1)}^{(i+1)}$ diterima sebagai $y_{1(n+1)}$, 
$y_{2(n+1)}, \theta_{1(n+1)}$ dan $\theta_{2(n+1)}$. Dan secara alami, nilai yang dievaluasi $y_{1(n+1)}, y_{2(n+1)}, \theta_{1(n+1)}$ dan $\theta_{2(n+1)}$ digunakan pada langkah berikutnya $(n+2)$ yang bertujuan untuk menemukan nilai $y_{1(n+2)}=y_{1}\left(t_{n+2}\right), y_{2(n+2)}=y_{2}\left(t_{n+2}\right), \theta_{1(n+2)}=\theta_{1}\left(t_{n+2}\right)$, dan $\theta_{2(n+2)}=\theta_{2}\left(t_{n+2}\right)$ dengan melalui tahap 3. Dan jika kondisi Error! Reference source not found. terpenuhi maka iterasi berhenti dan perhitungan hasil solusi numerik berhenti pada iterasi sebelumnya.

\section{Simulasi Numerik Model Gerak Osilasi Vertikal dan Torsional}

Simulasi numerik model gerak osilasi vertikal dan torsional menggunakan tiga simulasi. Simulasi dilakukan menggunakan langkah $h=0,01$ dan kriteria pemberhentian $\varepsilon=10^{-20}$. Pada Simulasi pertama menggunakan nilai awal $y(0)=14 ; \dot{y}(0)=0 ; \theta(0)=1,2$; dan $\dot{\theta}(0)=0$ diperoleh hasil sebagai berikut:

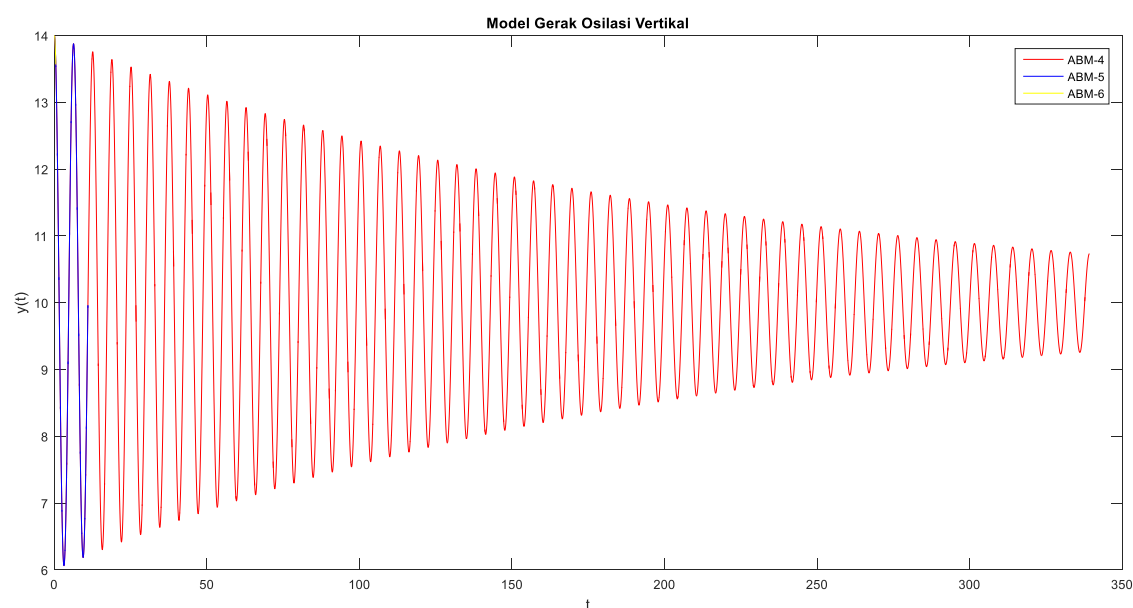

Gambar 1 Solusi Numerik Model Gerak Osilasi Vertikal dengan nilai awal $y(0)=14 ; \dot{y}(0)=0 ; \theta(0)=1,2$; dan $\dot{\theta}(0)=0$

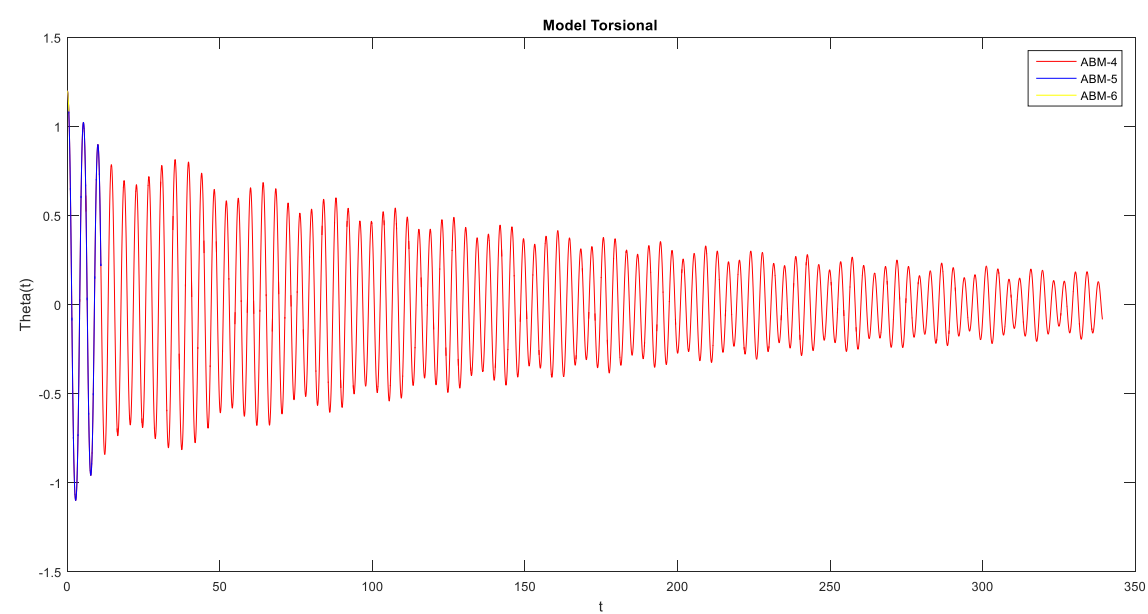

Gambar 2 Solusi Numerik Model Torsional dengan nilai awal $y(0)=14 ; \dot{y}(0)=0 ; \theta(0)=1,2$; dan

$$
\dot{\theta}(0)=0
$$

Gambar 1 dan Gambar 2 menunjukkan bahwa gerak osilasi vertikal menuju kesetimbangan pada titik 10 dan gerak torsional menuju kesetimbangan pada titik 0 , 
maka gerak osilasi vertikal dan torsional merupakan gerak harmonik teredam. Pada gambar tersebut juga menunjukkan bahwa solusi numerik metode Adams-BashforthMoulton menghasilkan iterasi waktu $t$ berbeda-beda, yaitu:

Tabel 1 Pemberhentian Iterasi Solusi Numerik Simulasi Pertama

\begin{tabular}{cc}
\hline Metode & waktu ke- \\
\hline ABM 4 & 339,29 \\
ABM 5 & 10,99 \\
ABM 6 & 0,47 \\
\hline
\end{tabular}

Hal ini karena pengaruh dari galat relatif dan kriteria pemberhentian $\varepsilon$. Oleh karena itu, Solusi numerik akan cepat memenuhi $\varepsilon$ sebandingan dengan besar orde pada metode Adams-Bashforth-Moulton. Sehingga perbandingan galat relatif pada solusi numerik simulasi pertama model gerak osilasi vertikal dan torsional sebagai berikut:

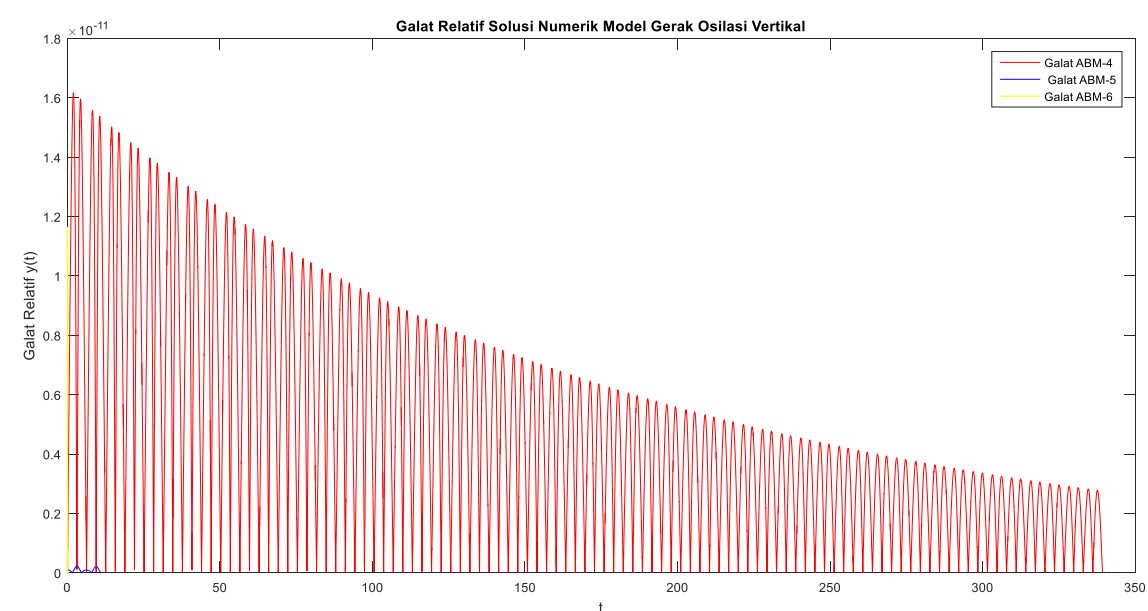

Gambar 3 Galat Relatif Metode Adams-Bashforth-Moulton pada Model Gerak Osilasi Vertikal saat Nilai Awal $y(0)=14 ; \dot{y}(0)=0 ; \theta(0)=1,2 ;$ dan $\dot{\theta}(0)=0$

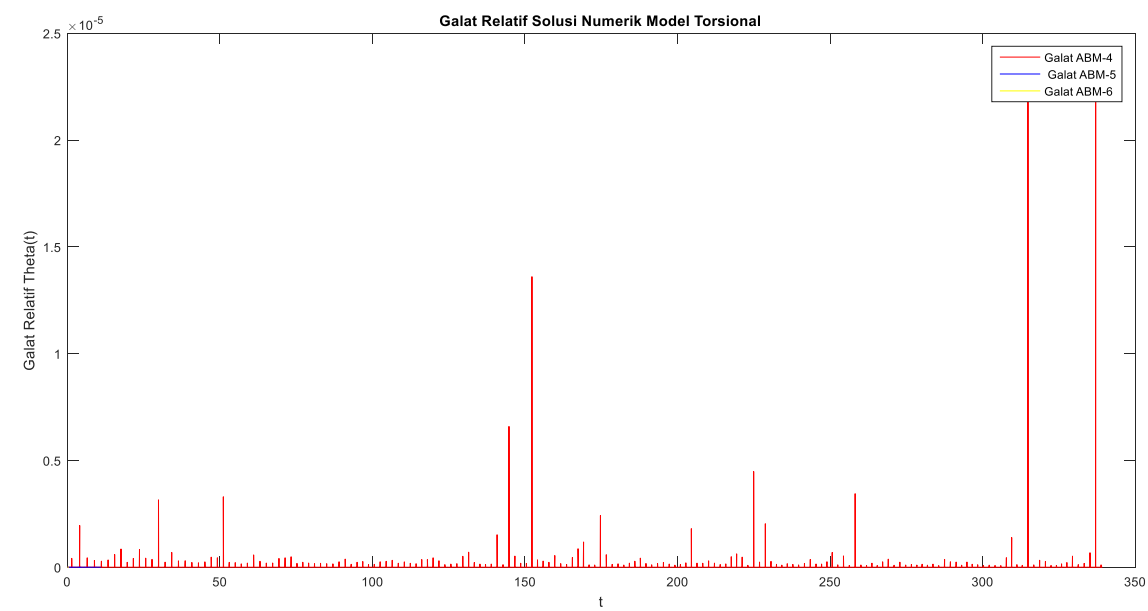

Gambar 4 Galat Relatif Metode Adams-Bashforth-Moulton pada Model Torsional saat Nilai Awal $y(0)=14$;

$$
\dot{y}(0)=0 ; \theta(0)=1,2 ; \text { dan } \dot{\theta}(0)=0
$$

Berdasarkan Gambar 4 dan Gambar 5 diperoleh hasil sebagai berikut: 
Tabel 2 Galat Relatif Model gerak Osilasi Vertikal dan Torsional Simulasi Pertama

\begin{tabular}{lcccc}
\hline \multirow{2}{*}{ Metode } & \multicolumn{2}{c}{ Gerak Osilasi Vertikal } & \multicolumn{2}{c}{ Gerak Torsional } \\
\cline { 2 - 5 } & Galat Relatif Terkecil & $\begin{array}{c}\text { Galat Relatif } \\
\text { Terbesar }\end{array}$ & Galat Relatif Terkecil & $\begin{array}{c}\text { Galat Relatif } \\
\text { Terbesar }\end{array}$ \\
\hline ABM 4 & $2,11051249275449 \times 10^{-16}$ & $1,61679962146804 \times 10^{-11}$ & $1,48661494274038 \times 10^{-14}$ & $2,32813713898227 \times 10^{-5}$ \\
ABM 5 & $3,55397128062262 \times 10^{-16}$ & $5,47995965187342 \times 10^{-12}$ & $8,21568807080448 \times 10^{-14}$ & $1,31808611543055 \times 10^{-8}$ \\
ABM 6 & $1,29519103495881 \times 10^{-16}$ & $1,16297751742516 \times 10^{-11}$ & $5,27487848189871 \times 10^{-14}$ & $3,21993591731726 \times 10^{-9}$ \\
\hline
\end{tabular}

Simulasi kedua menggunakan nilai awal $y(0)=6 ; \dot{y}(0)=0 ; \theta(0)=1,2$; dan $\dot{\theta}(0)=0$ diperoleh hasil sebagai berikut:

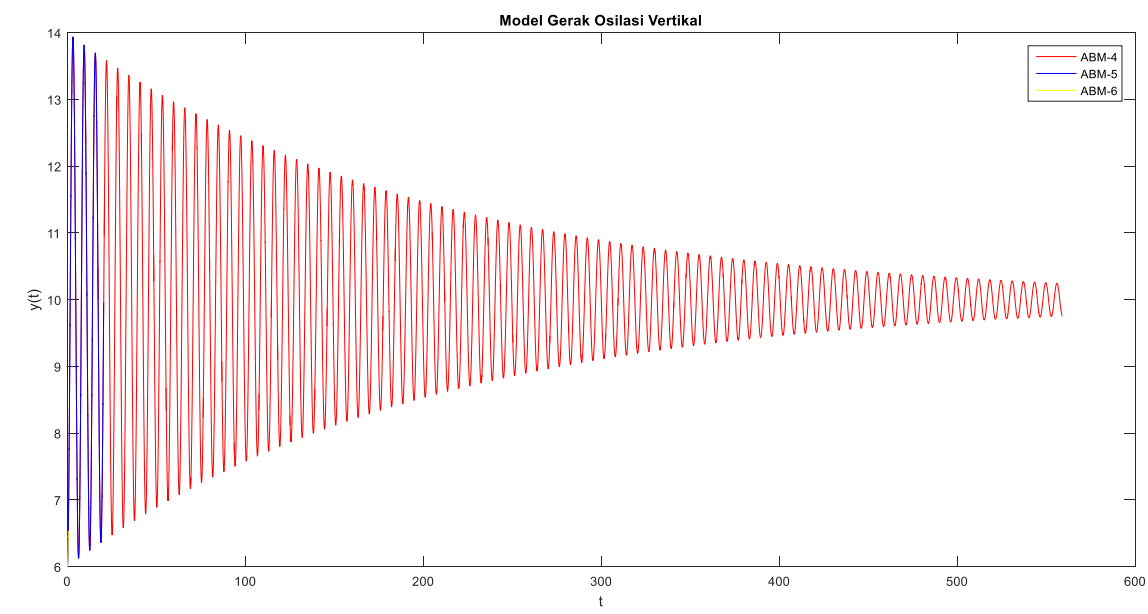

Gambar 5 Solusi Numerik Model Gerak Osilasi Vertikal dengan Nilai Awal $y(0)=6 ; \dot{y}(0)=0 ; \theta(0)=1,2$; dan $\dot{\theta}(0)=0$

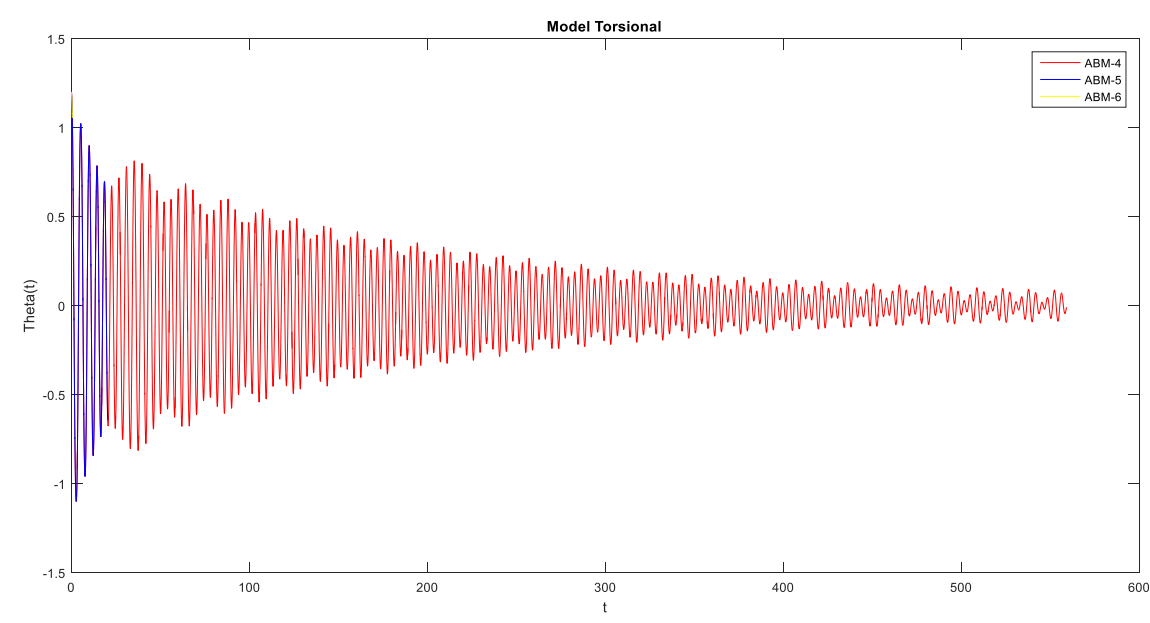

Gambar 6 Solusi Numerik Model Torsional dengan Nilai Awal $y(0)=6 ; \dot{y}(0)=0 ; \theta(0)=1,2$; dan

$$
\dot{\theta}(0)=0
$$

Gambar 5 dan Gambar 6 menunjukkan bahwa gerak osilasi vertikal menuju kesetimbangan pada titik 10 dan gerak torsional menuju kesetimbangan pada titik 0 , maka gerak osilasi vertikal dan torsional merupakan gerak harmonik teredam. Pada 
gambar tersebut juga menunjukkan bahwa solusi numerik metode Adams-BashforthMoulton menghasilkan iterasi waktu $t$ berbeda-beda, yaitu:

Tabel 3 Pemberhentian Iterasi Solusi Numerik Simulasi Kedua

\begin{tabular}{cc}
\hline Metode & waktu ke- \\
\hline ABM 4 & 559,21 \\
ABM 5 & 20,42 \\
ABM 6 & 0,53 \\
\hline
\end{tabular}

Hal ini karena pengaruh dari galat relatif dan kriteria pemberhentian $\varepsilon$. Oleh karena itu, Solusi numerik akan cepat memenuhi $\varepsilon$ sebandingan dengan besar orde pada metode Adams-Bashforth-Moulton. Sehingga perbandingan galat relatif pada solusi numerik simulasi pertama model gerak osilasi vertikal dan torsional sebagai berikut:

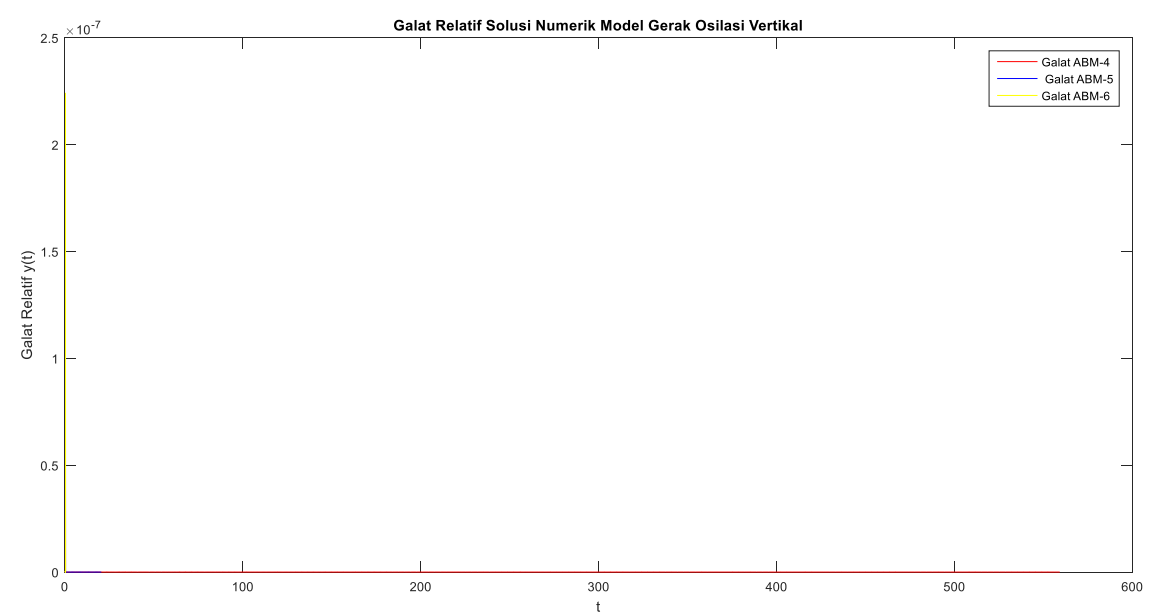

Gambar 7 Galat Relatif Metode Adams-Bashforth-Moulton pada Model Gerak Osilasi Vertikal saat Nilai Awal $y(0)=6 ; \dot{y}(0)=0 ; \theta(0)=1,2 ;$ dan $\dot{\theta}(0)=0$

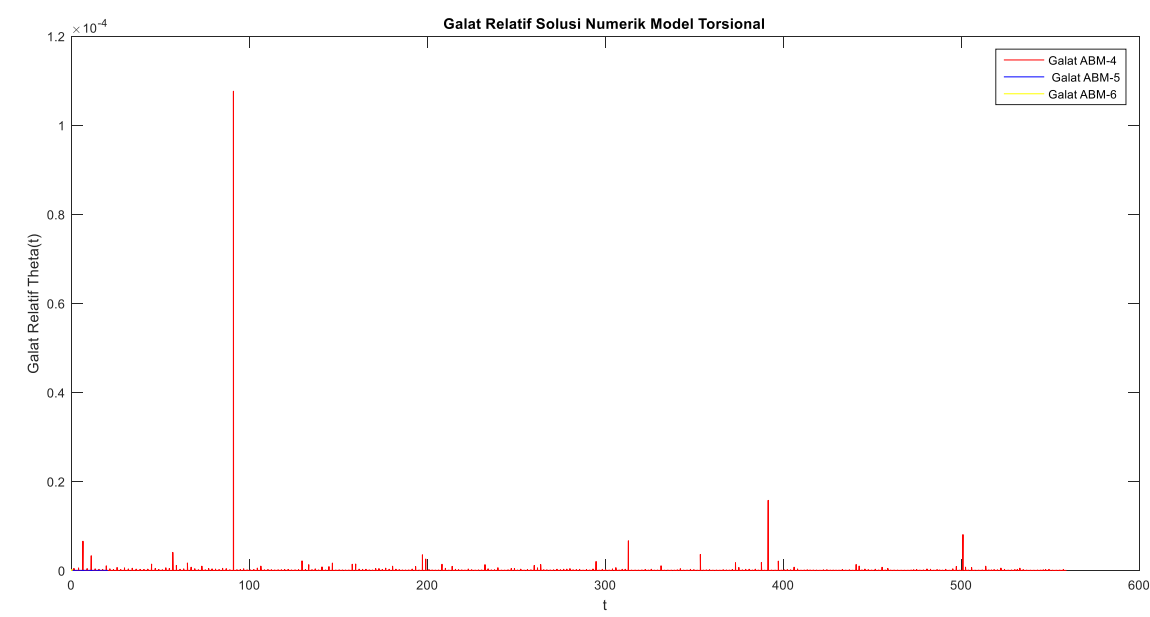

Gambar 8 Galat Relatif Metode Adams-Bashforth-Moulton pada Model Torsional saat Nilai Awal $y(0)=6$;

$$
\dot{y}(0)=0 ; \theta(0)=1,2 ; \text { dan } \dot{\theta}(0)=0
$$

Berdasarkan Gambar 7 dan Gambar 8 diperoleh hasil sebagai berikut:

Tabel 4 Galat Relatif Model gerak Osilasi Vertikal dan Torsional Simulasi Kedua

\section{Gerak Osilasi Vertikal}

Gerak Torsional 


\begin{tabular}{ccccc}
\hline Metode & Galat Relatif Terkecil & $\begin{array}{c}\text { Galat Relatif } \\
\text { Terbesar }\end{array}$ & Galat Relatif Terkecil & $\begin{array}{c}\text { Galat Relatif } \\
\text { Terbesar }\end{array}$ \\
\cline { 2 - 5 } ABM 4 & $1,39224000389205 \times 10^{-16}$ & $6,31691472681704 \times 10^{-8}$ & $9,76528635814982 \times 10^{-16}$ & 0,000107615464981596 \\
ABM 5 & $1,77412018055013 \times 10^{-16}$ & $1,13258607378114 \times 10^{-7}$ & $1,90608952722218 \times 10^{-16}$ & $1,08679781101889 \times 10^{-7}$ \\
ABM 6 & $1,35843400075013 \times 10^{-16}$ & $2,24060388991285 \times 10^{-7}$ & $5,94534689005873 \times 10^{-14}$ & $2,15673891072678 \times 10^{-7}$ \\
\hline
\end{tabular}

Simulasi ketiga menggunakan nilai awal $y(0)=-0,5 ; \dot{y}(0)=0 ; \theta(0)=0,5 ;$ dan $\dot{\theta}(0)=0$ diperoleh hasil sebagai berikut:

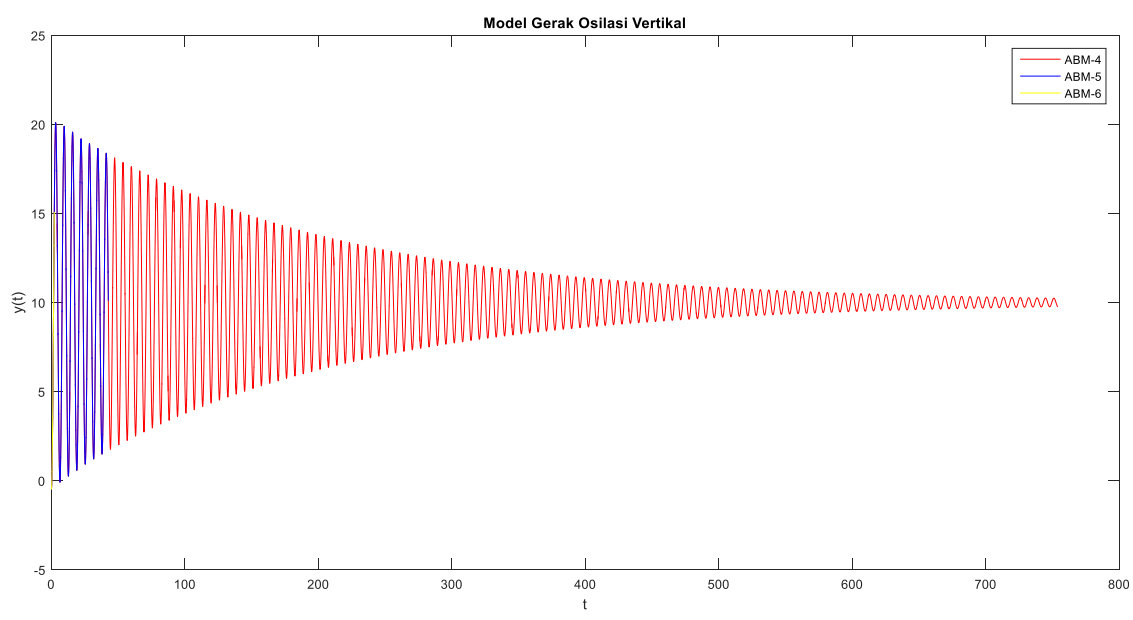

Gambar 9 Solusi Numerik Model Gerak Osilasi Vertikal dengan Nilai Awal $y(0)=-0,5 ; \dot{y}(0)=0$; $\theta(0)=0,5 ;$ dan $\dot{\theta}(0)=0$

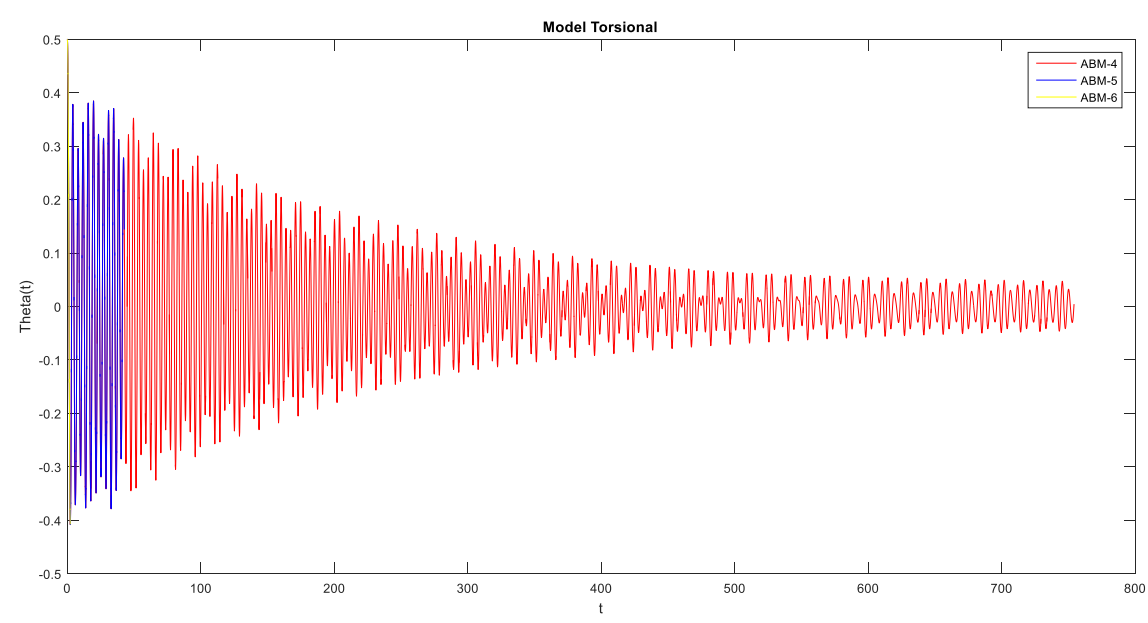

Gambar 10 Solusi Numerik Model Torsional dengan Nilai Awal $y(0)=-0,5 ; \dot{y}(0)=0 ; \theta(0)=0,5$; dan

$$
\dot{\theta}(0)=0
$$

Gambar 9 dan Gambar 10 menunjukkan bahwa gerak osilasi vertikal menuju kesetimbangan pada titik 10 dan gerak torsional menuju kesetimbangan pada titik 0 , maka gerak osilasi vertikal dan torsional merupakan gerak harmonik teredam. Pada 
gambar tersebut juga menunjukkan bahwa solusi numerik metode Adams-BashforthMoulton menghasilkan iterasi waktu $t$ berbeda-beda, yaitu:

Tabel 5 Pemberhentian Iterasi Solusi Numerik Simulasi Ketiga

\begin{tabular}{cc}
\hline Metode & waktu ke- \\
\hline ABM 4 & 754,28 \\
ABM 5 & 42,68 \\
ABM 6 & 2,19 \\
\hline
\end{tabular}

Hal ini karena pengaruh dari galat relatif dan kriteria pemberhentian $\varepsilon$. Oleh karena itu, Solusi numerik akan cepat memenuhi $\varepsilon$ sebandingan dengan besar orde pada metode Adams-Bashforth-Moulton. Sehingga perbandingan galat relatif pada solusi numerik simulasi pertama model gerak osilasi vertikal dan torsional sebagai berikut:

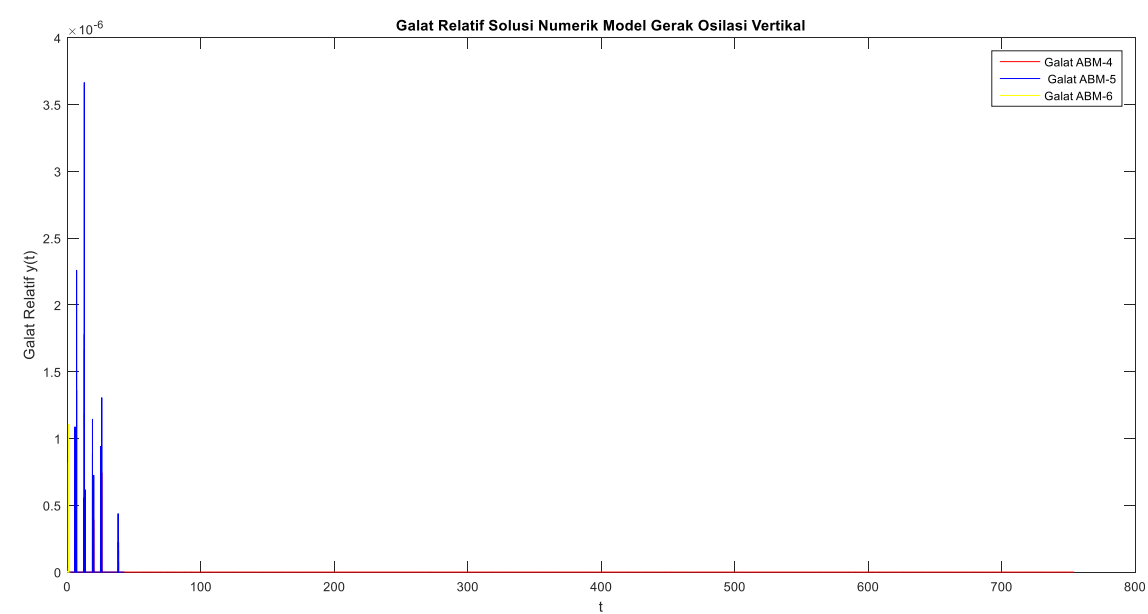

Gambar 11 Galat Relatif Metode Adams-Bashforth-Moulton pada Model Gerak Osilasi Vertikal saat Nilai Awal $y(0)=-0,5 ; \dot{y}(0)=0 ; \theta(0)=0,5 ;$ dan $\dot{\theta}(0)=0$

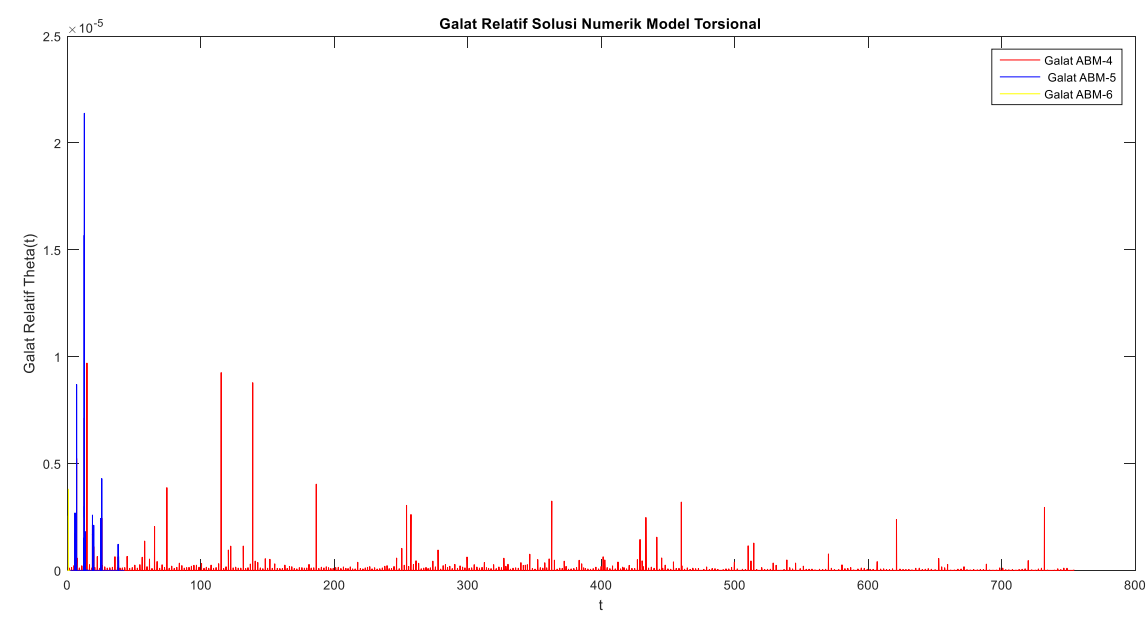

Gambar 12 Galat Relatif Metode Adams-Bashforth-Moulton pada Model Torsional saat Nilai Awal

$$
y(0)=-0,5 ; \dot{y}(0)=0, \theta(0)=0,5 ; \text { dan } \dot{\theta}(0)=0
$$

Berdasarkan Gambar 11 dan Gambar 12 diperoleh hasil sebagai berikut: 


\begin{tabular}{ccccc} 
Metode & Galat Relatif Terkecil & $\begin{array}{c}\text { Galat Relatif } \\
\text { Terbesar }\end{array}$ & Galat Relatif Terkecil & $\begin{array}{c}\text { Galat Relatif } \\
\text { Terbesar }\end{array}$ \\
\hline ABM 4 & $1,689912531783 \times 10^{-16}$ & $1,7786597453662 \times 10^{-6}$ & $5,62265610955897 \times 10^{-15}$ & $9,7001688041798 \times 10^{-6}$ \\
ABM 5 & $1,77817700485202 \times 10^{-16}$ & $3,66367558653258 \times 10^{-6}$ & $2,61206507694246 \times 10^{-15}$ & $2,1387087114825 \times 10^{-5}$ \\
& & & & \\
ABM 6 & $4,04196828767192 \times 10^{-16}$ & $1,10404638729739 \times 10^{-6}$ & $4,9675608426393 \times 10^{-16}$ & $3,80133175647868 \times 10^{-7}$
\end{tabular}

\section{KESIMPULAN}

Solusi numerik model gerak osilasi vertikal dan torsional mengunakan metode Adams-Bashforth-Moulton orde empat, lima, dan enam menunjukkan bahwa gerak osilasi dan gerak torsional merupakan gerak harmonik teredam, karena semakin waktu diperbesar gerak osilasi dan gerak torsional menuju ke titik kesetimbangan yaitu 10 untuk gerak osilasi dan 0 untuk gerak torsional. Dan galat relatif metode AdamsBashforth-Moulton pada model gerak osilasi vertikal akan cepat mendekati nilai 0 sepanjang sebanding dengan tinggi tingkat orde metode Adams-Bashforth-Moluton.

\section{DAFTAR RUJUKAN}

[1] R. O. Kwofie, A Mathematical model of a suspension bridge - case study: Adomi bridge, Atimoku, Ghana, 1(3): 47-62, 2012.

[2] D. C. Giancoli, Physics for Scientists and Engineers with Modern Physics, America: Pearson Education, Inc., 2009.

[3] R. Munir, Metode Numerik, Bandung: Informatika Bandung, 2010.

[4] S. Rosłoniec, Fundamental Numerical Methods for Electrical Engineering, Berlin: Springer-Verlag Berlin Heidelberg, 2008.

[5] R. L. Burden and J. D. Faires, Numerical Analysis Ninth Edition, Boston: Cengage Learning, 2010.

[6] P. J. McKenna, "Large torsional oscillations in suspension bridges revisited," Amer. Math. Monthly, pp. 1-18, 1999. 